\title{
2021 Handbook of Florida Water Regulation: Contact Agencies $^{1}$
}

\author{
Michael T. Olexa, Tatiana Borisova, and Jana Caracciolo
}

\section{Preface}

This handbook is designed to provide an accurate, current, and authoritative summary of the principal federal and state (Florida) laws that directly or indirectly relate to agriculture. This handbook provides a basic overview of the many rights and responsibilities that farmers and farmland owners have under both federal and state laws as well as the appropriate contact information to obtain more detailed information. However, the reader should be aware that because the laws, administrative rulings, and court decisions on which this handbook is based are subject to constant revision, portions of this publication could become outdated at any time. Several details of cited laws are also left out due to space limitations. This handbook is provided as an educational text for those interested in water use and water resource issues in Florida.

This handbook is distributed with the understanding that the authors are not engaged in rendering legal or other professional advice, and the information contained herein should not be regarded as a substitute for professional advice. This handbook is not all inclusive in providing information to achieve compliance with the federal and state laws and regulations governing water protection. For these reasons, the use of these materials by any person constitutes an agreement to hold harmless the authors, the UF/IFAS Center for Agricultural and Natural Resource Law, and UF/IFAS Extension for any liability claims, damages, or expenses that may be incurred by any person as a result of reference to or reliance on the information contained in this handbook. Note: UF/IFAS is the acronym for University of Florida, Institute of Food and Agricultural Sciences.

\section{Florida Agencies}

\section{S-1. Florida Water Management Districts}

Southwest Florida Water Management District

2379 Broad Street

Brooksville, FL 34604

(352) 796-7211

http://www.swfwmd.state.fl.us/

South Florida Water Management District

3301 Gun Club Road

West Palm Beach, FL 33406

(561) 686-8800

https://www.sfwmd.gov/

St. Johns River Water Management District

4049 Reid Street (Highway 100 West)

Palatka, FL 32178

(386) 329-4500

http://www.sjrwmd.com

1. This document is FE616, one of a series of the Food and Resource Economics Department, UF/IFAS Extension. Original publication date October 1998. Revised June 2017 and April 2021. Visit the EDIS website at https://edis.ifas.ufl.edu for the currently supported version of this publication.

2. Michael T. Olexa, professor, Food and Resource Economics Department, and director, UF/IFAS Center for Agricultural and Natural Resource Law; Tatiana Borisova, associate professor, Food and Resource Economics Department; and Jana Caracciolo, student, Levin College of Law; UF/IFAS Extension, Gainesville, FL 32611.

The Institute of Food and Agricultural Sciences (IFAS) is an Equal Opportunity Institution authorized to provide research, educational information and other services

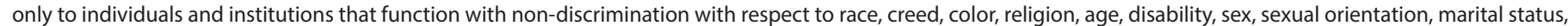

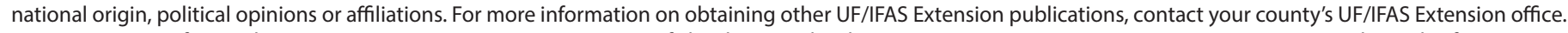
U.S. Department of Agriculture, UF/IFAS Extension Service, University of Florida, IFAS, Florida A \& M University Cooperative Extension Program, and Boards of County Commissioners Cooperating. Nick T. Place, dean for UF/IFAS Extension. 
Suwannee River Water Management District

9225 County Road 49

Live Oak, FL 32060

(386) 362-1001

https://www.mysuwanneeriver.com/

Northwest Florida Water Management District

81 Water Management Drive

Havana, FL 32333-4712

(850) 539-5999

http://www.nwfwater.com/

\section{S-2. Florida Department of Environmental Protection}

Florida Department of Environmental Protection

3900 Commonwealth Blvd M.S. 49

Tallahassee, FL 32399

(850) 245-2018

http://www.dep.state.fl.us/

\section{S-3. Florida Fish and Wildlife Conservation Commission}

Florida Fish and Wildlife Conservation Commission

Farris Bryant Building

620 South Meridian Street

Tallahassee, FL 32399-1600

(850) 488-4676

http://myfwc.com/

\section{S-4. Florida Department of Agriculture and Consumer Services}

Florida Department of Agriculture and Consumer Services The Capitol, Plaza Level Ten

400 South Monroe Street

Tallahassee, FL 32399-0800

$1-800-435-7352$

https://www.fdacs.gov/

FDACS - Division of Agricultural Environmental Services 3125 Conner Boulevard, Suite E

Tallahassee, FL 32399-1650

(850) 617-7900

https://www.fdacs.gov/Divisions-Offices/

Agricultural-Environmental-Services

FDACS-Florida Forest Service

3125 Conner Boulevard, Suite J

Tallahassee, FL 32399-1650

(850) 681-5800

https://www.fdacs.gov/Divisions-Offices/

Florida-Forest-Service
FDACS-Office of Agricultural Water Policy

The Mayo Building

407 South Calhoun Street, Mail Stop E1

Tallahassee, FL 32399-0800

(850) 617-1700

https://www.fdacs.gov/Divisions-Offices/

Agricultural-Water-Policy

\section{S-5. Florida Department of Health}

Florida Department of Health

Bureau of Environmental Health, Onsite Sewage Programs

4052 Bald Cypress Way, Bin\#A08

Tallahassee, FL 32399-1710

(850) 245-4250

http://www.floridahealth.gov/environmental-health/onsitesewage/index.html

\section{S-6. Florida Department of Economic Opportunity}

Florida Department of Economic Opportunity

Caldwell Building

107 East Madison Street

Tallahassee, FL 32399-4120

(850) 245-7105

http://www.floridajobs.org/

\section{S-7. Florida State Emergency Response Commission for Hazardous Materials}

Florida Division of Emergency Management

2555 Shumard Oak Blvd

Tallahassee, Fl 32399-2100

(850) 815-4000

https://www.floridadisaster.org/

\section{EPA National Offices and Telephone Numbers}

\section{F-1. Safe Drinking Water Hotline}

Hotline provides information on EPA drinking water regulations and programs, including local drinking water quality, drinking water standards, large capacity residential septic systems, etc.

Monday-Friday, 8:00 AM-4:30 PM, EST

Toll free (800) 426-4791 


\section{F-2. Environmental Emergency-National Response Center}

NRC is staffed 24 hours a day, 7 days a week, for reporting spills and environmental violations.

Toll free (800) 424-8802

\section{F-3. Toxic Chemical Release Emergencies (EPCRA)}

EPCRA Hotline is for reporting toxic chemical releases into the environment.

Monday-Friday, 10:00 AM-5:00 PM, EST

Toll free (800) 424-9346

\section{F-4. TSCA Assistance Information Service}

Toxic Substances Control Act (TSCA) provides information about toxic substances and compliance with TSCA regulations.

Monday-Friday, 8:30 AM-5:00 PM, EST

(202) 554-1404

\section{F-5. National Pesticide Information Center}

Hotline provides information on pesticides and pesticide poisonings, and spills and exposure.

Monday-Friday, 8:00 AM-12:00 PM, EST

Toll free (800) 858-7378

In case of an immediate emergency, call 911

\section{Numbers within EPA Region 4 (includes Florida)}

\section{L-1. General Information for Region 4}

United States Environmental Protection Agency

61 Forsyth Street SW

Atlanta, GA 30303

Toll free (800) 241-1754

https://www.epa.gov/aboutepa/

about-epa-region-4-southeast
L-2. Hazardous Waste Enforcement and Compliance Section

United States Environmental Protection Agency

RCRA Enforcement, Tenth Floor

61 Forsyth Street SW

Atlanta, GA 30303

(404) 562-8594

Supervises compliance with RCRA and resolves citizen problems dealing with hazardous waste management.

\section{L-3. Groundwater and SDWA Enforcement Section}

US EPA Region 4 Ground Water and SDWA Enforcement Section

Safe Drinking Water Branch

61 Forsyth Street SW

Atlanta, GA 30303-8960

(404) 562-9399

\section{L-4. Emergency Superfund Branch}

Handles response to spills and other CERCLA/RCRA issues.

Toll free (800) 424-8802 (National Response Center)

(404) 562-8700 (EPA Region 4)

\section{L-5. Water Protection Division}

Compliance with Clean Water Act and groundwater programs

(404) 562-9345

\section{Acknowledgments}

The authors are indebted to the personnel of both state and federal agencies who provided their time and advice in the preparation of this handbook. We acknowledge Carol Fountain and Susan Gildersleeve at the University of Florida for their assistance in editing this handbook. We also acknowledge funding received for updating this publication from the James S. and Dorothy F. Wershow Agricultural Law Endowment. 